\title{
No meio da ontologia havia um vírus: notas acerca de uma abertura cosmopolítica em tempos de pandemia
}

\author{
In the midst of ontology there was a virus: notes about a cosmopolitical opening \\ in times of pandemic
}

\section{Alexandre Simão de Freitas*}

Resumo: O texto desdobra algumas notas críticas em torno de um experimento ensaístico insvirado na recedcão polêmica do posicionamento de vários filósofos acerca da atual situação de pandemia, entrelaçando os temas da geontologia e da virada ontológica. Admitese, nesse sentido, que a filosofia, ela mesma, tornou-se viral, o que, dentre outras consequências, produz uma abertura cosmopolítica que convoca a filosofia a experimentar uma espécie de mutação de perspectiva, alterando seus modos habituais de lidar com os problemas ontológicos.

Palavras-chave: Pandemia; Vírus; Cosmopolítica; Geontologia

Abstract: The text unfolds some critical notes around an essay experiment inspired by the controversial reception of the positioning of several philosophers about the current pandemic situation, intertwining the themes of geontology and ontological turning point. It is admitted, in this sense, that philosophy itself has become viral, which, among other consequences, has produced a cosmopolitical opening that calls philosophy to experience a kind of mutation of perspective, changing its usual ways of dealing with ontological problems.

Keywords: Pandemic; Virus; Cosmopolitics; Geontology

\section{Notas introdutórias}

As medidas tomadas para conter o avanço do novo coronavírus fizeram eclodir uma série de intervenções e análises filosóficas que ultrapassaram o âmbito estrito da infeção biológica. Tudo indica que a filosofia se tornou viral. Essa situação contribuiu para evidenciar, ainda que de forma difusa, uma abertura emergindo por entre as ruínas das formas clássicas de hermenêutica e compartilhamento filosóficos, uma vez que o debate em torno do novo coronavírus surge ameaçando infectar o corpo já combalido de uma filosofia movida pelos vetores autoimunes de suas máquinas antropológicas.

Assim, não foi por acaso que a reflexão do filósofo italiano Giorgio Agamben, publicada em 26 de fevereiro de 2020 , esteve no centro da elevação repentina da curva de propagação dessa nova filosofia viral. Dramatizada por meio do posicionamento de Jean Luc Nancy às suas reflexões, as análises do pensador italiano foram condensadas na fórmula polêmica a invenção de uma epidemia, a qual parece conter um poder infeccioso tão letal quanto o próprio coronavírus, colocando a comunidade filosófica em estado de alerta ${ }^{1}$.

Contudo, em A comunidade dos abandonados: uma resposta a Agamben e Nancy, Divya Dwivedi e Shaj Mohan lembram que, dentre os muitos mal-entendidos filosóficos

\footnotetext{
${ }^{1}$ Ver AGAMBEN et al. Sopa de Wuhan, p. 17.
}

* Professor do Departamento de Administração Escolar e Planejamento Educacional, Universidade Federal de Pernambuco, Recife, PE. E-mail: alexkilaya@uol.com.br ORCID: https://orcid.org/o000-0003-0982-6581 
provocados por esse debate está o fato de que se tem persistido em uma abordagem que sempre mobiliza o “valor' do homem”. Para os filósofos indianos, as intervenções filosóficas permanecem discutindo o sentido do estado de emergência sem retirar do centro de suas pressuposições o fato de que persistimos em ler o mundo sempre com as lentes excepcionais do anthropos, elidindo o cerne oculto do problema: estamos sempre em busca de proteger nossos sistemas imunitários constituindo exceções na natureza.

Como consequência, os humanos monopolizam o privilégio da sensação de que são os únicos abandonados. Em contrapartida, quase nunca, esse abandono abre a possibilidade de prestar atenção nas outras formas de vidas². Nessa perspectiva, o vírus vem nos acordar do sonho metafísico cultivado zelosamente pelos modernos que concebem o relacionamento com a natureza como uma guerra do espírito contra a matéria inerte. $\mathrm{O}$ vírus vem lembrar ainda aquilo que nossos horizontes ontológicos têm invisibilizado e subordinado em nome de uma soberania antropocêntrica de caráter paranoico, exigindo uma outra linguagem para as múltiplas experiências de ser tratadas como sem valor ${ }^{3}$.

Essa situação convoca a filosofia a experimentar uma espécie de mutação de perspectiva, pois altera significativamente seus modos habituais de lidar com os problemas ontológicos, bem como com suas implicações éticas e políticas. Com base nessas premissas, desdobramos a seguir algumas notas analíticas, ensaiando uma espécie de crítica experimental inspirada na recepção polêmica do posicionamento externado por vários filósofos contemporâneos acerca da pandemia provocada pela emergência do novo coronavírus, entrelaçando no percurso os temas da geontologia e da virada ontológica. Um convite a confabular outros encontros possíveis entre o pensamento, o vírus e a filosofia.

\section{Quem o vírus pensa que é?}

Pradeu, Kostyrka e Dupré ressaltam que os vírus têm estado virtualmente ausentes da filosofia4. Uma situação que não deixa de ser surpreendente não apenas porque eles constituem as entidades biológicas mais abundantes e diversificadas da natureza, mas sobretudo por seus recorrentes impactos sociais. A viralidade tem sido uma questão filosoficamente não tematizada5 .

A decretação de pandemia em função do novo coronavírus veio alterar essa situação. A filosofia passou a se ocupar, para além dos problemas específicos relacionados à definição e taxonomia que apontam para o lugar do vírus no mundo biológico, com as graves questões políticas perspectivadas pela nova situação de viralidade, redimensionando problemas como: Os vírus são seres vivos? Um vírus é um organismo? Onde e quando um vírus começa e termina?

Todas essas questões afetam o centro pulsante da ontologia ocidental: a noção de vida e suas distinções notáveis entre entes vivos e não vivos ${ }^{6}$. O vírus, como sabemos, é uma entidade movida por uma ontologia instável, capaz de transgredir as fronteiras entre a morte e a vida. Trata-se de um ente que articula as esferas comumente cindidas do orgânico, do anorgânico e mesmo dos artefatos produzidos pela engenharia humana. Para Zizek, isso torna bastante difícil pensar o vírus uma vez que sua "repetitiva vida pré-sexual" aponta para

\footnotetext{
${ }^{2}$ DWIVEDI; MOHAN. La comunità degli abbandonati, s/p.

${ }^{3}$ MOHAN. Cosa ci porta avanti.

4 PRADEU, KOSTYRKA e DUPRÉ, Understanding Viruses: Philosophical Investigations, p. o1.

${ }^{5}$ Sobre o uso da noção de viralidade ver VERMAIRE, A viralidade em Saramago e Ionesco.

${ }^{6}$ Cf. AGAMBEN, $O$ aberto. $O$ homem e o animal.
} 
a existência de uma espécie de "subcamada de vida". Desse modo, eles são ora considerados como "unidades químicas não vivas", ora como "organismos"7.

Na verdade, os vírus não estariam nem vivos nem mortos nos sentidos usuais que projetamos nesses termos. Pois, se, por um lado, o seu desejo de se replicar não é condição suficiente para indicar que se trata de um organismo vivo. Por outro, é um erro pensar que eles são uma forma elementar de vida, da qual se desenvolveram as formas de vida mais complexas. É justamente o contrário o que se passa. Os vírus põem em ação uma forma de existência parasitária que lhes permite se replicarem através de outros organismos, usandoos como uma espécie de máquina de reprodução. Como resultado, eles configuram uma dimensão da realidade marcada pela captura e mistura de diferentes códigos em uma espécie de evolução a-paralela ${ }^{8}$. No limite, essa forma excêntrica do existir faz com que os vírus ocupem o lugar paradoxal de signo absoluto do vivo em geral.

Esse é um diagnóstico que perturba a compreensão que a filosofia ocidental tem do processo de materialização ontológica dos seres. Por isso, Elizabeth Povinelli tem chamado a atenção para a urgência de questionar um pressuposto tácito armado por nossas reflexões ontológicas ancoradas no que ela denomina de imaginário do carbono ${ }^{9}$. O desafio aqui é colocar em quarentena as divisões ontológicas dominantes na filosofia ocidental que supõem uma oposição abissal entre geos e bios, e cujo fio articulador reside na compreensão de que a agência diz respeito a uma capacidade exclusiva dos humanos. Nenhuma dessas oposições, contudo, consegue se manter imune à influência daquilo que Povinelli chama de geontopoder, isto é, uma forma de governamentalidade própria do contexto neoliberal tardio colonizador $^{10}$, que funciona menos como um conjunto de proposições sobre o estado do mundo do que como um eixo em torno do qual gira todo o aparato de conhecimento propositivo a respeito do mundo.

Assim, a biontologia ocidental funciona como uma proposição não proposicional, ou seja, como um tipo de declaração que não pode ser colocada em questão. Mais: quando isso acontece seus oponentes são tratados como irracionalistas ou neoanimistas. Por isso, dentre as várias figuras que abrem uma mutação no imaginário social, científico e filosófico, o vírus talvez seja a figura mais radical, uma vez que sua existência passa incólume à divisão vida/não vida, resistindo, simultaneamente, aos modelos de pensamento e de governamento sustentados na oposição entre vida e morte, entre vida e não vida.

Decerto, nenhuma pandemia viral tem o poder, por si só, de suspender afirmações e práticas que tomam como evidente a proeminência da proteção humana diante das rochas ou do próprio vírus. Mas o que interessa, do ponto de vista filosófico, é justamente o estado de suspensão que permite interromper, mesmo que provisoriamente, a aceitação tácita daquela dicotomia, abrindo espaço para novas vozes e outras imagens de pensamento.

Nessa direção, os filósofos-tradutores das cosmologias indígenas da América do Sul têm ressaltado que, para muitos povos, as entidades que habitam o domínio natural não podem ser apreendidas sem mais segundo a categoria de não humanos ${ }^{11}$. Os andinos, por sua vez, incluem suas montanhas na categoria de seres-da-terra, os quais não se pode determinar se pertencem à categoria da Natureza ou da Humanidade, sendo percebidas como "fonte da vida e da morte"12.

\footnotetext{
7 ZIZEK, El coronavírus es un golpe al capitalismo a lo Kill Bill, p 21.

${ }^{8}$ DELEUZE e GUATTARI, Mil Platôs. Capitalismo e esquizofrenia, vol. 1, p. 18.

9 POVINELLI, As quatro figuras da "sexualidade" nos colonialismos de povoamento, p. 11.

${ }^{10}$ POVINELLI, Geontologies. A Requiem for Late Liberalism.

${ }^{11}$ Ver KRENAK, O modo de funcionamento da humanidade entrou em crise.

12 CADENA, Indigenous Cosmopolitics in the Andes: Conceptual Reflections beyond 'Politics', p. 338.
} 
As categorizações que giram em torno dos vetores opositivos geos e bios não são suficientes para determinar o estatuto ontológico de um conjunto multifacetado de seres, uma vez que as cosmopolíticas da terra tornam inoperantes essas mesmas dicotomias. Nesses regimes de pensamento, as várias criaturas do cosmos são atravessadas potencialmente por um excesso ontológico, o que borra as fronteiras supostamente bem demarcadas da ontologia ocidental ${ }^{13}$.

Isso significa que em tempos de pandemia, o novo coronavírus acabou pot tornar ativo aquilo que, nas cosmologias ocidentais, sempre foi tratado como mero pano de fundo inerte. Em termos da agência viral, a distinção entre natureza e sociedade ou entre epidemiologia e economia se dissolve, mediante um movimento transespecífico que constitui distintas ondas de interação que se propagam subitamente sem uma ordem, direção ou finalidade previsíveis.

Como resultado, além de tornar problemática as concepções de vida e de organismo ainda prevalentes nas ciências naturais e sociais, a lógica viral não pressupõe nenhuma intencionalidade unificada, nenhum plano predeterminado que possa orientar e coordenar pacificamente o entrelaçamento complexo entre os seres orgânicos e inorgânicos. Esse tipo de situação contribui para constranger os que se pretendem responsáveis por nosso destino comum, sejam governantes, especialistas ou grandes empresários, fazendo-os perceber que "a vida é muito mais caótica do que os economistas e darwinistas haviam imaginado"14.

A razão é que, do ponto de vista cosmopolítico, o vírus não parece operar como um diplomata, isto é, ele não faz uso da gramática política dominante. Sua linguagem é a da intrusão, provocando medo e pânico, ao mesmo tempo em que desconcerta aqueles que enxergam sua intrusão como um irritante desvio das metas de desenvolvimento e acumulação infinita. Assim, o acontecimento suscitado pela intrusão viral se revela paradoxalmente na abertura de uma percepção de que "talvez não saibamos o que achamos que sabemos"15.

O encontro cosmopolítico com atual coronavírus evidencia a urgência de pensar novas maneiras de habitar ontologicamente a Terra, interrogando a suposta legitimidade de determinadas relações ou interesses humanos à custa de outras relações e interesses de outros seres. Logo, a atual crise epidemiológica, demanda uma reflexão filosófica aguda sobre que tipos de seres e perspectivas vêm sendo sistematicamente excluídos de nossa ontologia ${ }^{16}$.

\section{Faz sentido uma guerra ao vírus?}

Um dos efeitos inesperados da situação pandêmica atual, portanto, é a abertura de uma reflexão ontológica que passa a reconhecer as contribuições oriundas das filosofias dos inúmeros povos extramodernos, forçando a filosofia a considerar seres e situações que, de outro modo, poderiam sequer se fazer notar. Nesse aspecto, seria preciso problematizar o uso da linguagem bélica que tem sido mobilizada para lidar com os efeitos do coronavírus ${ }^{17}$. Como lembra Vermeire, não é de hoje que o vírus constitui, para o ocidente, uma expressão

\footnotetext{
13 Ver CASTRO, Cosmopolíticas da Terra: Modos de existência e resistência no Antropoceno, p. 92.

${ }^{14}$ LATOUR, Face à Gaïa. Huit conférences sur le nouveau régime climatique, p.138.

15 STENGERS, Matters of Cosmopolitics: On the Provocations of Gaïa, p. 177.

16 TSING, Viver nas ruínas: paisagens multiespécies no Antropoceno, p. 156.

${ }^{17}$ BARZAGUI, O inimigo não é o vírus, p. o6.
} 
encarnada da degradação extrema: o vírus é a peste. Essa imagem matricial tem parasitado nossas representações literárias, científicas e sociais ${ }^{18}$.

Enquanto figura arqueogenealógica da viralidade, a peste reitera todo tipo de desordem. Como consequência, o imaginário da peste se associa a outra força destrutiva que é a guerra. Juntas, a peste e a guerra, contribuem para contaminar nossa atmosfera vital produzindo uma instabilidade considerada mortífera para a vida em comum e forçando a segregação das populações. Contudo, a tarefa de domesticar o caos provocado pela peste não é uma tarefa simples, pois abre a sociedade para inimigos sorrateiros, adversários que são constantemente conjurados. Aliás, essa é a crueldade imputada ao vírus: ser um inimigo invisível.

Nesse contexto, a ideia de uma guerra dos mundos, sinalizada por vários pensadores para articular os dilemas provocados pela biontologia ocidental, pode nos ajudar a identificar, desde o âmbito filosófico, as equivocações inerentes ao modo como temos lidado com os conflitos entre seres situados em topologias distintas dos nossos dispositivos ontológicos $^{19}$. A nosso ver, tal inflexão desdobraria e contribuiria também para uma descolonização filosófica.

Dito de outro modo: a guerra dos mundos diz respeito menos a instauração de um conflito contra nossos supostos inimigos, no caso específico o novo coronavírus, e mais a um desdobramento possível de uma investigação sobre os modos de existência ${ }^{20}$, capaz de fornecer visibilidade a histórias que pareciam seguir caminhos próprios: a história dos sistemas planetários, a história da vida na Terra, incluindo a vida humana, e a história do capitalismo ${ }^{21}$.

Ao interseccionar essas múltiplas histórias criaríamos as condições para decidir se vamos continuar com a guerra generalizada que vem aniquilando o planeta ou se vamos rever nossa ordem ontológica imperial e seus procedimentos devastadores. Vale lembrar que não há razão para supor que a mera constatação da intrusão viral vai unir toda a humanidade em prol de um objetivo comum. As próprias divergências filosóficas nas formas de traduzir a língua do vírus seguirão prevalecendo. É preciso, contudo, que a guerra velada que constitui o sonho europeu de moldar toda a Terra à sua imagem e semelhança seja declarada ${ }^{22}$.

Sem isso, as diferentes perspectivas dos mundos em relação não podem ser apresentadas, e essa é uma condição para que se possa distinguir aliados e inimigos. Essa é uma exigência vital na situação pandêmica em que vivemos, pois a brutalidade do novo coronavírus corresponde à brutalidade daquilo que o provocou: um modelo de desenvolvimento cego às suas consequências, ou, mais precisamente, que só leva em conta as consequências do seu ponto de vista.

Lutar, portanto, contra o vírus não faz sentido, trata-se antes de aprender a compor com ele, assumindo o compromisso de nos valermos da nossa própria impotência para fazer surgir no mundo outras possibilidades de existir ${ }^{23}$. Trata-se então de pensar a pandemia viral menos como uma guerra e mais como um acontecimento que faz irromper regimes ontológicos distintos do dominante, "mais próximos dos animais e dos rochedos" 24 , bem como de todas as existências não decalcadas da imagem do "Patriarcado Capitalista

\footnotetext{
${ }^{18}$ VERMEIRE, A viralidade em Saramago e Ionesco, p. 28.

19 CASTRO, Guerra e paz no Antropoceno: uma análise da crise ecológica segundo a obra de Bruno Latour, p. 34.

${ }^{20}$ LATOUR, Investigação sobre os modos de existência: uma antropologia dos modernos, p. 35.

${ }^{21}$ CHAKRABARTY, O clima da história: quatro teses.

${ }^{22}$ AUGUSTO, Guerra e pandemia: produção de um inimigo invisível contra a vida livre, p. 05.

${ }^{23}$ STENGERS, I. Au temps des catastrophes: résister à la barbarie qui vient, p. 69.

${ }^{24}$ DELEUZE e GUATTARI, Mil Platôs. Capitalismo e Esquizofrenia. Vol. 4, p. 49.
} 
Branco" 25 e suas práticas necropolíticas ${ }^{26}$. Diferentemente, o que uma guerra de mundos clama e conclama é uma nova ideia de tradução como tentativa de tornar visíveis as reivindicações, bem como os modos próprios de existir, de rexistir e de ocupar a Terra ${ }^{27}$.

Essa é a demanda, a questão endereçada desde o vírus à filosofia. Pensar traduzindo, isto é, criando mundos em que as multiplicidades possam exprimir suas pretensões e ter suas existências reconhecidas. Gilles Deleuze afirmava que, não sendo a filosofia uma potência, como são os Estados e o capitalismo, ela não pode contra eles empreender batalhas, mas apenas "uma guerra sem batalha, uma guerra de guerrilha” ${ }^{28}$. Esse diagnóstico oferece uma indicação precisa.

O que pode a filosofia em tempos de pandemia? Quais são suas armas? Considerando o que foi exposto até aqui, isto é, que o modo de existência do vírus pressupõe uma espécie de bricolagem multiespécie ${ }^{29}$, deveríamos abandonar, antes de tudo, nossas ideias ontológicas tradicionais, a fim de reaprendermos a produzir novos possíveis que impeçam que sufoquemos, que impeçam a asfixia. Afirmar a vida, portanto, para suscitar saídas ao sufocamento da vida mesma ${ }^{30}$.

\section{Fragmentos finais: para uma geofilosofia viral}

$\mathrm{Na}$ pandemia do novo coronavírus tudo se passa como se determinadas reivindicações de proteção imunitária ameaçassem outras demandas, aquelas que os Estados, os mercados e as corporações ditam. Em uma direção oposta, a propagação do contágio social, e não apenas biológico, do coronavírus demonstra o quanto somos interdependentes de forças situadas em um reino plural de existência. Assim, a primeira lição profunda do vírus está sendo transmitida: a desordem nos parâmetros basilares das dinâmicas da Terra já se faz sentir de inúmeras formas, indicando que "a ausência de futuro já começou"31.

A principal aprendizagem geofilosófica do vírus que hoje nos força a pensar é essa profunda agitação da Terra, essa suspensão generalizada, provocando, simultânea e paradoxalmente, uma perturbação na ação política ${ }^{32}$. Infelizmente ainda cultivamos o péssimo hábito de, em tempos de crise, apelar a teorias que não apenas respondam e esclareçam, mas sobretudo prevejam, antecipem e resolvam tudo por nós. Por isso, essas considerações inconclusivas não ensejam resultados muito precisos, tampouco oferece meios para a verificação da validade de tudo que foi proposto.

Em suma, o que uma filosofia viral parece disposta a nos oferecer é muito pouco diante dos desafios que teremos pela frente. Contudo, custa-nos crer que o encontro com o vírus não produzirá novas aberturas. Aprendido como uma pura força de mutação, o vírus é também uma brecha que contribui para descolonizar nossos modos usuais de fazer filosofia e redimensionar o estatuto de nossas divisões ontológicas. O vírus tornou urgente a radicalidade ético-política do tratamento com que nos dispomos a pensar os seres da

\footnotetext{
${ }^{25}$ HARAWAY, A Cyborg Manifesto: Science, Technology, and Socialist-Feminism in the Late Twentieth Century, p. 149.

${ }^{26}$ MBEMBE, A. Necropolítica.

${ }^{27}$ CASTRO, Cosmopolíticas da Terra: Modos de existência e resistência no Antropoceno, p. 152.

${ }^{28}$ DELEUZE e GUATTARI, Capitalismo e Esquizofrenia. Vol. 4, p. 7.

${ }^{29}$ COCCIA, $O$ vírus é uma força anárquica de metamorfose, p. 05.

${ }^{30}$ MBEMBE, O direito universal à respiração, p. o8.

${ }^{31}$ DANOWSKI; CASTRO, Há mundo por vir? Ensaio sobre os medos e os fins, p. 18.

${ }^{2}$ PRECIADO, Aprendiendo del vírus.
} 
natureza e os mundos considerados não humanos. Negar isso é abdicar da tarefa de pensar deixando nosso destino à mercê dos especialistas encarregados de gerir a precariedade.

\section{Referências}

AGAMBEN, G. et al. Sopa de Wuhan. Editorial ASPO: Barcelona, 202o. Disponível em: https://bit.ly/zauNBgG.

AUGUSTO, A. Guerra e pandemia: produção de um inimigo invisível contra a vida livre. Disponível em: https://n-1edicoes.org/o18 Acesso em: 18/04/2020.

BARZAGUI, $O$ inimigo não é o vírus. Disponível em: https://n-1edicoes.org/o23 Acesso em 18/04/2020.

CADENA, M. Indigenous Cosmopolitics in the Andes: Conceptual Reflections beyond 'Politics'. In: Cultural Anthropology, vol. 25, no. 2, p. 334-370, 2010.

CASTRO, A. Cosmopolíticas da Terra: Modos de existência e resistência no Antropoceno. 2019. 303f. Tese (Doutorado em Filosofia). PUC-SP.

CASTRO, A. Guerra e paz no Antropoceno: uma análise da crise ecológica segundo a obra de Bruno Latour. Rio de Janeiro: Editora Autografia, 2017.

CHAKRABARTY, D. O clima da história: quatro teses. Sopro, v. 91. 2013.

COCCIA, $O$ vírus é uma força anárquica de metamorfose. Disponível em: https://n1edicoes.org/o21 Acesso em: 18/04/2020.

DANOWSKI, D.; VIVEIROS DE CASTRO, E. Há mundo por vir? Ensaio sobre os medos e os fins. Florianópolis: Cultura e Barbárie, 2014.

DELEUZE, G.; GUATTARI, F. Mil Platôs. Capitalismo e esquizofrenia, vol. 1. São Paulo: Editora 34, 1995.

DELEUZE, G.; GUATTARI, F. Mil Platôs. Capitalismo e Esquizofrenia. Vol. 4. São Paulo: Editora 34, 2012.

DWIVEDI, D.; MOHAN, S. La comunità degli abbandonati. Disponível em: https://antinomie.it/index.php/2020/03/12/la-comunita-degli-abbandonati/ Acesso em: 12 de março de 2020.

HARAWAY, D. The Biopolitics of Postmodern Bodies: Determinations of Self inImmune System. Discourse. v. 1, n. 1, p. 3-43, 1989.

HARAWAY, D. A Cyborg Manifesto: Science, Technology, and Socialist-Feminism in the Late Twentieth Century. In: Simians, Cyborgs and Women: The Reinvention of Nature. New York; Routledge. p.149-181, 1991.

KRENAK, A. O modo de funcionamento da humanidade entrou em crise. Disponível em: https://www.em.com.br/app/noticia/pensar/2020/o4/o3/interna pensar,1135082/funcionam ento-da-humanidade-entrou-em-crise-opina-ailton-krenak.shtml Acesso em: 05/04/2020.

LATOUR, B. War and Peace in an Age of Ecological Conflicts. Revue Juridique de l'Environnement, Vol.1, pp. 51-63, 2014.

LATOUR, B. Investigação sobre os modos de existência. Uma antropologia dos modernos. Petrópolis, Rio de Janeiro: Vozes, 2019. 
LATOUR, B. Face à Gaïa. Huit conférences sur le nouveau régime climatique. Paris: La Découverte - Les Empêcheurs de Penser en Ronde, 2015.

MBEMBE, O direito universal à respiração. Disponível em: https://n-1edicoes.org/ozo Acesso em: 18/04/2020.

MBEMBE, A. Necropolítica. São Paulo: n-1 Edições, 2018.

MOHAN, S. Cosa ci porta avanti. Disponível em: https://antinomie.it/index.php/2020/03/30/cosa-ci-porta-avanti/ Acesso em: 30 de março de 2020.

POVINELLI, E. As quatro figuras da "sexualidade" nos colonialismos de povoamento. Cadernos Pagu, (41), p. 11-18, 2013.

POVINELLI, E. Geontologies. A Requiem for Late Liberalism. Durham and London: Duke University Press, 2016.

PRADEU, T.; KOSTTRKA, G.; DUPRÉ, J. Understanding Viruses: Philosophical Investigations. In: Studies in History and Philosophy of Biological and Biomedical Sciences, pp. $\quad 2016.17,2$ Disponível em: http://www.sciencedirect.com/science/article/pii/S1369848616300024. Acesso em 31/03/2020.

PRECIADO, P. Aprendiendo del vírus. Disponível em: https://elpais.com/elpais/2020/03/27/opinion/1585316952 026489.html Acesso em: 28 de março de 2020.

STENGERS, I. Au temps des catastrophes: résister à la barbarie qui vient. Paris: Les Empêcheurs de penser en rond, 2009.

STENGERS, I. Matters of Cosmopolitics: On the Provocations of Gaïa. Entrevista concedida a Heather Davis e Etienne Turpin. In: TURPIN, E. (ed.). Architecture in the Anthropocene: Encounters Among Design, Deep Time, Science and Philosophy. Michigan: Open Humanities Press, 2013.

TSING, A. L. Viver nas ruínas: paisagens multiespécies no Antropoceno. Brasília: IEB Mil Folhas, 2019.

VERMEIRE, S. A viralidade em Saramago e Ionesco. 2014. 327f. Tese (Doutorado em Ciências da Literatura). Universidade do Minho, Portugal.

ZIZEK, S. El coronavírus es un golpe al capitalismo a lo Kill Bill... In: AGAMBEN, Giorgio et al. Sopa de Wuhan. Editorial ASPO: Barcelona, 2020. Disponível em: https://bit.ly/zauNBgG. 